\title{
UNITED NATIONS CONVENTION AGAINST CORRUPTION DALAM SISTEM HUKUM INDONESIA
}

\author{
Eddy O.S Hiariej*
}

Departemen Hukum Pidana, Fakultas Hukum Universitas Gadjah Mada

Jalan Sosio Justisia No. 1, Bulaksumur, Sleman, D.I. Yogyakarta 55281

\begin{abstract}
The Indonesian government had ratified the United Nations Convention Against Corruption ['UNCAC'] through Act No. 7 of 2006. However, the Indonesian Act on Anti-Corruption has yet to be synchronized with UNCAC. On one hand, corruption has become a massive issue in Indonesia, but on the other hand, the existing Anti-Corruption Act has yet to be in compliance with the relevant international instrument. Therefore, the implementation of UNCAC has become more urgent. Aside from the need to counter corruption efficiently and effectively, UNCAC calls upon the need for international cooperation against corruption.
\end{abstract}

Keywords: international crime, corruption crime, united nations convention against corruption.

\section{Intisari}

Pemerintah Indonesia telah meratifikasi United Nations Convention Against Corruption (UNCAC) dengan Undang-Undang Nomor 7 Tahun 2006. Akan tetapi sampai dengan saat ini, undang-undang pemberantasan tindak pidana korupsi belum disesuaikan dengan konvensi tersebut. Di satu sisi korupsi yang terjadi di Indonesia begitu masif, sedangkan di sisi lain undang-undang pemberantasan tindak pidana korupsi yang ada masih belum disesuaikan dengan instrumen internasional. Dalam konteks ini, implementasi UNCAC menjadi suatu hal yang urgen. Selain memberantasan korupsi secara efisien dan efektif, UNCAC mensyaratkan adanya kerjasama internasional dalam pemberantasan korupsi.

Kata kunci: kejahatan internasional, kejahatan korupsi, konvensi PBB menganai antikorupsi.

\section{Pokok Muatan}

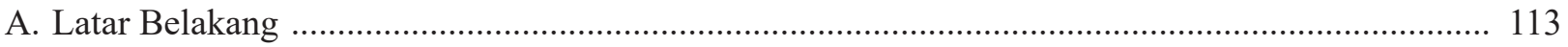

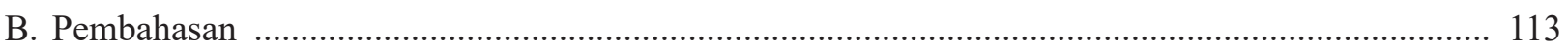

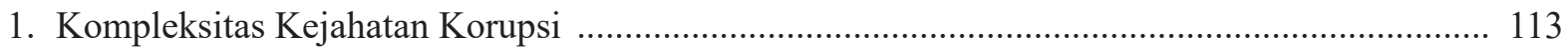

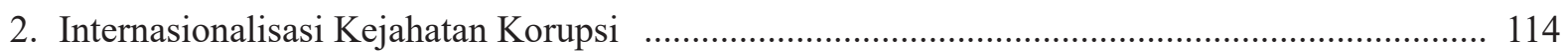

3. Hubungan Antara Hukum Pidana Internasional Dan Hukum Pidana Nasional ......................... 116

4. Pengaruh Asas-Asas Hukum Pidana Internasional ...................................................................... 121

5. Raison D'Etre Implementasi UNCAC Di Indonesia .............................................................. 123

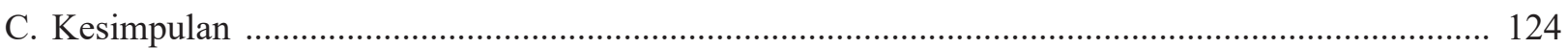

Alamat korespondensi: eddyosh@ugm.ac.id. 


\section{A. Latar Belakang}

Het recht hinkt achter de feiten aan. Sebuah ungkapan dalam Bahasa Belanda yang berarti hukum itu ketinggalan dari peristiwanya. Penulis sendiri tidak sependapat dengan ungkapan tersebut sebab recht is geen person (hukum bukanlah orang) melainkan suatu sistem yang terdiri dari sub-sub sistem dan jika terdapat kekurangan pada satu subsistem akan dilengkapi oleh subsistem lainnya. Hukum di sini diartikan sebagai hukum tertulis atau undang-undang yang perubahannya harus melalui prosedur sehingga tidak dapat setiap kali dilakukan untuk disesuaikan dengan keadaan ${ }^{1}$.

Dalam konteks pemberantasan korupsi, perubahan undang-undang telah dilakukan pascareformasi. Pertama, undang-undang nomor 31 tahun 1999 yang secara tegas mencabut dan menggantikan undang-undang nomor 3 tahun 1971 tentang pemberantasan tindak pidana korupsi. Kedua, undang-undang nomor 20 tahun 2001 yang mengubah dan menambahkan beberapa pasal yang sudah ada dalam undang-undang sebelumnya.

Dalam rangka memperkuat instrumen pemberantasan korupsi di Indonesia, selain dibentuk komisi pemberantasan korupsi berdasarkan undangundang nomor 30 tahun 2002, Pemerintah Indonesia juga telah meratifikasi United Nations Convention Against Corruption (UNCAC) atau Konvensi Antikorupsi PBB dengan undang-undang nomor 7 tahun 2006. Menjadi perdebatan, apakah UNCAC yang telah diratifikasi serta merta dapat diberlakukan sebagai instrumen pemberantasan korupsi di Indonesia ataukah tidak dapat diterapkan sebelum melakukan perubahan dan penyesuaian dengan undang-undang nasional terkait pemberantasan korupsi yang kita miliki.

Tulisan singkat ini mencoba mengulas diskursus tersebut. Agar sitematis, tulisan ini terdiri dari beberapa subjudul. Pertama, kejahatan korupsi itu sendiri. Kedua, internasionalisasi kejahatan korupsi. Ketiga, hubungan antara hukum pidana nasional dan hukum pidana internasional. Keempat, asas-asas dalam hukum pidana internasional. Kelima, raison d'etre implementasi UNCAC di Indonesia.

\section{B. Pembahasan}

\section{Kompleksitas Kejahatan Korupsi}

Korupsi yang berasal dari bahasa latin corruptio $^{2}$ atau menurut Webster Student Dictionary adalah corruptus, sesungguhnya berasal dari suatu kata latin yang lebih tua yakni corrumpere. Corrumpere dapat diartikan sebagai kebusukan, keburukan, kebejatan, ketidakjujuran, dapat disuap, tidak bermoral, penyimpangan dari kesucian, katakata atau ucapan yang menghina atau memfitnah. Dalam studi kejahatan, korupsi bersama-sama dengan prostitusi adalah kejahatan tertua di dunia. Diperkirakan kejahatan korupsi dan prostitusi akan tetap berlangsung selama ada kehidupan di dunia.

Masih dalam studi kejahatan, paling tidak ada 9 tipe korupsi. Pertama, political bribery adalah termasuk kekuasaan di bidang legislatif sebagai badan pembentuk undang-undang. Secara politis badan tersebut dikendalikan oleh suatu kepentingan karena dana yang dikeluarkan pada masa pemilihan umum sering berkaitan dengan aktivitas perusahaan tertentu. Kedua, political kickbacks, yaitu kegiatan-kegiatan yang berkaitan dengan sistem kontrak pekerjaan borongan antara pejabat pelaksana dan pengusaha yang memberi peluang untuk mendatangkan banyak uang bagi pihakpihak yang bersangkutan. Ketiga, election fraud adalah korupsi yang berkaitan langsung dengan kecurangan pemilihan umum. Keempat, corrupt campaign practice adalah praktek kampanye dengan menggunakan fasilitas negara. ${ }^{3}$

Kelima, discretionery corruption yaitu

\footnotetext{
Sudikno Mertokusumo, 2003, Mengenal Hukum: Suatu Pengantar, Liberty, Yogyakarta, hlm. 103.

Fockemma, S.J. Andreae, 1951 Rechtsgeleerd Handwoordenboek, Groningen-Djakarta: Bij J.B.

Wolter Uitgeversmaatschappij N.V sebagaimana di kutip Andi Hamzah, 1984, Korupsi di Indonesia Masalah dan Pemecahannya, Gramedia Pustaka Utama, hlm. 7.

Piers Beirne dan James Messerschmidt, 1995, Criminology, second edition, Harcourt Brage College Publishers, hlm. $295-297$.
} 
korupsi yang dilakukan karena ada kebebasan dalam menentukan kebijakan. Keenam, illegal corruption yakni korupsi yang dilakukan dengan mengacaukan bahasa hukum atau interpretasi hukum. Ketujuh, ideological corruption ialah perpaduan antara discretionery corruption dan illegal corruption yang dilakukan untuk tujuan kelompok. Kedelapan, political corruption adalah penyelewengan kekuasaan atau kewenagan yang dipercayakan kepadanya untuk mendapatkan keuntungan pribadi atau kelompok yang berkaitan dengan kekuasaan. Kesembilan, mercenary corruption yaitu menyalahgunakan kekuasaan semata-mata untuk kepentingan pribadi.

Korupsi dalam sudut pandang hukum pidana berarti mengacu kepada Undang-Undang Pemberantasan Tindak Pidana Korupsi. Berdasarkan undang-undang a quo, terdapat 30 perbuatan yang dikualifikasikan sebagai tindak pidana korupsi yang adalah sebagai berikut:

1. Korupsi yang berkaitan dengan kerugian keuangan negara sebanyak 2 pasal

2. Korupsi yang berkaitan dengan suapmenyuap sebanyak 12 pasal

3. Korupsi yang berkaitan dengan penggelapan dalam jabatan sebanyak 5 pasal

4. Korupsi yang berkaitan dengan pemerasan sebanyak 2 pasal

5. Korupsi yang berkaitan dengan perbuatan curang sebanyak 2 pasal

6. Korupsi yang berkaitan dengan pengadaan sebanyak 1 pasal

7. Korupsi yang berkaitan dengan gratifikasi sebanyak 1 pasal

\section{Internasionalisasi Kejahatan Korupsi}

Istilah internasionalisasi kejahatan dapat diartikan sebagai proses penetapan tindakantindakan tertentu sebagai kejahatan internasional. Tindakan-tindakan tertentu yang kemudian dinyatakan sebagai kejahatan internasional dapat melalui doktrin, kebiasaan atau praktek hukum internasional. ${ }^{4}$ Proses penetapan tersebut biasanya dibahas oleh suatu komite atau badan yang bersifat ad-hoc kemudian memperoleh persetujuan dari suatu konvensi yang diadakan khusus untuk itu. Proses pembahasan suatu tindakan tertentu sebagai kejahatan internasional biasanya dilakukan oleh international law commission atau komisi hukum internasional yang berada di bawah PBB.

Secara garis besar ada dua kategori kodifikasi kejahatan internasional dalam berbagai treaty. Pertama, treaties yang secara tegas menyatakan perbuatan-perbuatan yang dilarang dan dinyatakan sebagai kejahatan di bawah hukum internasional. Kedua, treaties yang tidak menyatakan perbuatanperbautan yang dilarang sebagai suatu kejahatan, tetapi mewajibakan para negara peserta untuk menuntut atau mengekstradisi para pelaku tindakan tersebut berdasarkan hukum nasional ${ }^{5}$.

Ada lima unsur tingkah laku tertentua yang mana jika salah satu unsur saja terpenuhi, maka tingkah laku tersebut dapat dikualifikasikan sebagai kejahatan internasional. Pertama, tingkah laku yang dilarang berakibat signifikan terhadap kepentingan internasional, khususnya perdamian dan keamanan internasional. Kedua, tingkah laku yang dilarang merupakan perbuatan yang buruk dan dianggap mengancam nilai-nilai yang dianut bersama oleh masyarakat dunia, termasuk apa yang telah dianggap oleh sejarah sebagai tingkah laku yang menyentuh nurani kemanusiaan. Hal ini didukung banyak pendapat internasional dimana tindakan suap dalam lingkup internasional harus diberantas. ${ }^{6}$

Ketiga, tingkah laku yang dilarang memiliki implikasi transnasional yang melibatkan atau mempengaruhi lebih dari satu negara dalam perencanaan, persiapan atau perbuatannya, baik melalui keragaman kewarganegaraan para pelaku kejahatan atau korban atau perlengkapan yang digunakan melebihi batas-batas negara. Keempat,

M. Cherif Bassiouni, 2003, Introduction To International Criminal Law, Transnational Publisher, Inc. Ardsley, New York, hlm. 109. Illias Bantekas and Susan Nash, 2007, International Criminal Law, Third edition, Routledge Cavendish, London And New York, hlm. 6. Rajib Sanyal, "Determinants of Bribery in International Business: The Cultural and Economic Factors", Journal of Business Ethics, Vol 59, 2005, hlm. 139. 
tingkah laku yang membahayakan perlindungan terhadap kepentingan internasional atau terhadap orang yang dilindungi secara internasional. Kelima, tingkah laku tersebut melanggar kepentingan internasional yang dilindungi namun tidak sampai pada tahap yang disebut pada poin pertama dan kedua, namun karena sifat dasarnya, tingkah laku tersebut dapat dicegah dan ditekan melalui kriminalisasi internasional. ${ }^{7}$

Dalam konteks kejahatan korupsi dengan merujuk pada UNCAC, kategori kodifikasi internasionalisasi kejahatan korupsi termasuk treaty yang tidak menyatakan perbuatan-perbautan yang dilarang sebagai suatu kejahatan internasional, tetapi mewajibakan para negara peserta untuk menuntut atau mengekstradisi para pelaku tindakan tersebut berdasarkan hukum nasional sebagaimana termaktub dalam Pasal 30 UNCAC. Demikian pula berdasarkan unsur-unsur internasionalisasi kejahatan sebagaimana yang diungkapkan oleh Bassiouni di atas, kejahatan korupsi termasuk tingkah laku yang melanggar kepentingan internasional yang karena sifat dasarnya, tingkah laku tersebut dapat dicegah dan ditekan melalui kriminalisasi internasional.

Dalam backround paper UNCAC paling tidak ada enam dampak korupsi ${ }^{8}$ yang melatarbelakangi internasionalisasi kejahatan korupsi. Pertama, korupsi dianggap merusak demokrasi. Kedua, korupsi dianggap merusak aturan hukum. Ketiga, korupsi dapat menggangu pembangunan berkelanjutan. Keempat, korupsi dianggap merusak pasar. Kelima, korupsi dapat merusak kualitas hidup. Keenam atau yang terakhir, korupsi dianggap melanggar hak-hak asasi manusia. Hal ini berkaitan dengan hak-hak atas kehidupan yang layak bagi masyarakat namun terabaikan karena negara tidak memiliki cukup anggaran untuk meningkatkan kesejahteraan rakyat akibat korupsi. Bahkan dalam sebuah penelitian, secara tegas bahwa Korupsi adalah pelanggaran terhadap Hak Asasi Manusia. ${ }^{9}$

Berdasarkan keenam dampak korupsi tersebut, adapun tujuan UNCAC adalah sebagai berikut : Pertama, mencegah dan membasmi korupsi secara efisien dan efektif. Oleh karena itu, harus ada koordinasi diantara institusi-institusi pemberantasan korupsi termasuk jaminan dan perlindungan terhadap masyarakat yang melaporkan adanya dugaan korupsi. Kedua, kerjasama internasional dan bantuan teknis termasuk pengembalian aset kejahatan. Kerjasama di sini tidak hanya diantara negara peserta konvensi, namun kerjasama juga dilakukan dengan negara-negara yang bukan merupakan state party dari konvensi tersebut. Dalam hal ini harus dipahami bahwa dengan pembentukan UNCAC, teknis hukum acara anti korupsi terutama dalam pengembalian asset telah diatur sebagai landasan kerjasama antar Negara. ${ }^{10}$ Ketiga, integritas, akuntabilitas dan transparansi serta manajemen yang tepat di sektor publik.

Berdasarkan internasionalisasi kejahatan, dalam konteks hukum pidana internasional, $\mathrm{M}$. Cherif Bassiouni membagi hirarki kejahatan internasional menjadi tiga. Pertama, kejahatan internasional yang disebut sebagai international crimes' adalah bagian dari jus cogens. Tipikal dan karakter dari 'international crime' berkaitan dengan perdamaian dan keamanan manusia serta nilai-nilai kemanusiaan yang fundamnetal. Kedua, kejahatan internasional yang disebut sebagai 'international delicts. Tipikal dan karakter 'international delicts' berkaitan dengan kepentingan internasional yang dilindungi meliputi lebih dari satu negara atau korban dan kerugian yang timbul berasal lebih dari satu negara. Ketiga, kejahatan internasional yang disebut dengan istilah 'international infractions'.

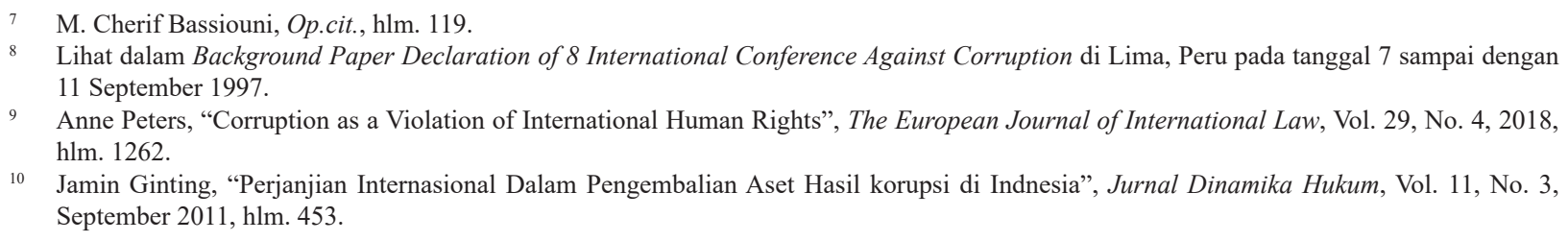


Dalam hukum pidana internasional secara normatif, 'international infraction' tidak termasuk dalam kategori 'international crime' dan 'intetrnational delicts'.

Kejahatan internasional yang dikemukakan oleh Bassiouni, tidak berkorelasi postif dengan penegakan hukum pidana internasional itu sendiri. Kejahatan-kejahatan yang dikategorikan sebagai "international crimes" yang menempati hirarki teratas dalam kejahatan internasional, hanya empat kejahatan yang menjadi yurisdiksi Mahkamah Pidana Internasional, yakni agresi, genosida, kejahatan terhadap kemanusiaan dan kejahatan perang. Selain itu dapat saja dikemudian hari berdasarkan perkembangan doktrin dan praktek kebiasaan dalam hukum pidana internasional maupun konvensi, suatu kejahatan internasional dapat berubah hirarkinya. Maksudnya, suatu kejahatan inetrnasional yang tadinya termasuk dalam hirarki international infractions dapat saja berubah dan dimasukkan sebagai international delicts, bahkan sebagai "international crimes". Sebagai misal, piracy pada awalnya berada pada hirarki "international crime", namun dalam perkembangannya piracy hanya menempati tingkatan sebagai "international delicts".

Dalam kaitannya dengan kejahatan korupsi, saat ini berdasarkan kelima unsur-unsur internasionalisasi kejahatan, korupsi berada pada hiraki yang terakhir, yakni "international infractions". Akan tetapi, perlu dipahami pula bahwa saat ini ada dua kejahatan internasional yang sedang dibahas oleh International Law Commission untuk menjadi yurisdiksi International Criminal Court. Kedua kejahatan tersebut adalah narkotika dan korupsi. Jika kemudian Majelis Umum PBB menyetujui kejahatan narkotika dan korupsi sebagai yurisdiksi International Criminal Court akan membawa konsekunsi hirarki kejahatan korupsi yang tadinya sebagai "international infractions" menjadi "international crimes". Tegasnya, kejahatan korupsi akan berada pada hirarki teratas dari kejahatan internasional.

\section{Hubungan Antara Hukum Pidana Inter- nasional Dan Hukum Pidana Nasional}

Hubungan antara hukum pidana internasional dan hukum pidana nasional secara mutatis mutandis tidak terlepas dari hubungan antara hukum internasional dan hukum nasional yang akan merujuk kepada dua teori. Pertama, teori monisme yang menyatakan bahwa hukum internasional dan hukum nasional merupakan dua aspek dari satu sistem hukum. Kedua, teori dualisme yang menyatakan bahwa hukum internasional dan hukum nasional masing-masing merupakan dua sistem hukum yang berbeda. ${ }^{11}$

Teori monisme melihat hukum internasional dan hukum nasional merupakan satu kesatuan sistem hukum berupa kaidah-kaidah yang mengikat individu, negara maupun kesatuan lainnya yang bukan negara. ${ }^{12}$ Hukum internasional mengikat individu secara kolektif, sedangkan hukum nasional mengikat individu secara perorangan. Teori dualisme melihat hubungan antara hukum internasional dan hukum nasional sebagai dua hal yang terpisah, terlebih dalam dunia modern yang mana negara mempunyai kedaulatan dan kesederajatan. ${ }^{13}$ Baik hukum internasional, maupun hukum nasional adalah aturan-aturan hukum yang bebas terpisah dan tidak dapat dikatakan bahwa hukum internasional adalah superior dari hukum nasional, begitu pula sebaliknya. ${ }^{14}$

Terkait berlakunya hukum internasional dalam hukum nasional, menurut paham monisme, hukum internasional dapat berlaku dan merupakan bagian dari hukum nasional, khususnya bagi perjanjian-perjanjian yang merupkan self executing treaty. Sementara paham dualisme berpendapat

\footnotetext{
Sugeng Istanto, 1998, Hukum Internasional, Penerbitan Universitas Atma Jaya Yogyakarta, hlm. 5.

J.G. Starke, 2001, Pengantar Hukum Internasional, 1, Edisi Kesepuluh, Sinar Grafika, Jakarta, hlm. 98

Malcolm N. Shaw, 2004, International Law, $5^{\text {th }}$ Edition, Cambridge University Press, hlm. $99-100$.

D.J. Harris, 1998, Cases and Materiils On International Law, Sweet \& Maxwell, London, hlm. 68.
} 
bahwa hak dan kewajiban yang ditetapkan oleh hukum internasional melalui sebuah treaty tidak mempunyai pengaruh terhadap hukum nasional tanpa ada pengesahan dari negara. Kalaupun berpengaruh, maka berlakunya hukum internasional dalam hukum nasional kedudukannya tetap berada di bawah konstitusi negara. ${ }^{15}$

Diskursus antara paham monisme dan paham dualisme dalam hubungan antara hukum pidana internasional dan hukum pidana nasional dalam perkembangannya terdapat perubahanperubahan yang cukup prinsip. Dalam hukum pidana internasional pertentangan pendapat antara paham monisme dan paham dualisme perihal subjek hukum sudah tidak relevan lagi. Dalam perkembangannya, subjek hukum internasional yang dapat dikenakan pertanggungjawaban pidana antara lain adalah individu. Artinya, hukum pidana internasional mengikat individu secara perorangan dalam kaitannya dengan tindakan-tindakan yang dikualifikasikan sebagai kejahatan internasional.

Individu sebagai subjek hukum pidana internasional jelas tidak sesuai dengan paham monisme yang menyatakan bahwa hukum internasional mengikat individu secara kolektif, terlebih dengan paham dualisme yang menyatakan bahwa subjek hukum internasional secara ekslusif hanyalah negara. Selain itu hampir semua tindakantindakan yang dikualifikasikan sebagai kejahatan internasional telah diatur dan merupakan bagian dari hukum nasional masing-masing negara, kendatipun negara tersebut bukan merupakan state party atau negara peserta dari treaty crime yang mengkualifikaikan suatu tindakan sebagai kejahatan internasional. ${ }^{16}$

Hubungan antara hukum pidana internasional dan hukum pidana nasional adalah hubungan yang bersifat komplementer antara satu dengan yang lain dan memiliki arti penting dalam rangka penegakan hukum pidana itu sendiri. Hal ini jelas terlihat banyaknya asas dalam hukum pidana nasional diadopsi sebagai asas-asas dalam hukum pidana internasional. Dalam ketentuan KUHP di semua negara, khususnya berkaitan dengan asas berlakunya hukum pidana menurut tempat, tidak hanya meliputi teritorial negara tersebut tetapi juga meliputi tempat-tempat tertentu yang dianggap perluasan teritorial, kendatipun berada di wilayah negara lain. Demikian pula sebaliknya, tindakantindakan yang dikualifikasikan sebagai kejahatan internasional oleh hukum pidana internasional kemudian diadopsi ke dalam ketentuan-ketentuan dalam hukum pidana nasional dengan tujuan agar kejahatan tersebut tidak terjadi di negaranya.

Dengan demikian kejahatan-kejahatan yang diatur dalam UNCAC dan belum ada padanannya di dalam undang-undang pemberantasan tindak pidana korupsi yang kita miliki bersifat pelengkap terhadap sistem pemberantasan korupsi secara kesleuruhan, khususnya, menyangkut substansi korupsi itu sendiri. Tidak seperti konvensi lainnya yang merumuskan unsur-unsur suatu kejahatan atau definisi mengenai suatu kejahatan, UNCAC tidak mendefinisikan apa yang dimaksud dengan korupsi. Akan tetapi, dalam Bab III UNCAC terkait kriminalisasi dan penegakan hukum, terdapat 11 perbuatan yang dikriminalisasikan sebagai korupsi. Secara garis besar, kesebelas perbuatan tersebut adalah : Pertama, bribery of national public officials atau penyuapan pejabat-pejabat publik nasional (Pasal 15). Kedua, bribery of foreign public officials and officials of public international organizations atau penyuapan pejabat-pejabat publik asing dan pejabat-pejabat dari oraganisasi-organisasi internaional publik (Pasal 16).

Ketiga, embezzlement, misappropriation or other diversion of property by a public official atau penggelapan, penyelewenagan atau pengalihan kekayaan dengan cara lain oleh pejabat publik (Pasal 17). Keempat, trading in influence atau memperdagangkan pengaruh (Pasal 18). Kelima, abuse of function atau penyalahgunaan fungsi (Pasal 
19). Keenam, illicit enrichment atau memperkaya secara tidak sah (Pasal 20). Ketujuh, bribery in the private sector atau penyuapan di sektor swasta (Pasal 21). Kedelapan, emblezzement of property in the private sector atau penggelapan kekayaan dalam sektor swasta (Pasal 22). Kesembilan, laundering of proceeds of crime atau pencucian hasil kejahatan (Pasal 23). Kesepuluh, concealment atau penyembunyian (Pasal 24). Kesebelas, obstruction of justice atau perbuatan menghalanghalangi proses pengadilan (Pasal 25).

Dari kesebelas tindakan yang dikriminalisasikan dalam UNCAC, ada yang bersifat mandatory offences dan ada yang bersifat nonmandatoty offences. Kedua sifat ini tidak terlepas dari kesepakatan negara-negara peserta dalam konvensi tersebut. Jika suatu tindakan yang dikriminalisasikan bersifat mandatory berarti ada kesepakatan seluruh peserta konvensi untuk mengatur tindakan tersebut dalam undang-undang nasionalnya sehingga menimbulkan kewajiban dari state party. Sebaliknya, jika suatu tindakan bersifat non-mandatory berarti tidak ada kesepakatan diantara para peserta konvensi untuk menyatakan tindakan tersebut sebagai kriminal.

Ada 5 tindakan yang dikriminalisasikan dalam UNCAC yang bersifat mandatory offences. Masing-masing adalah: bribery of national public officials; bribery of foreign public officials and officials of public international organizations; embezzlement, misappropriation or other diversion of property by a public official; laundering of proceeds of crime dan obstruction of justice. Sedangkan 6 tindakan lainnya yang bersifat nonmandatory offences adalah: trading in influence; abuse of function; illicit enrichment; bribery in the private sector; emblezzement of property in the private sector dan concealment.
Perumusan tindakan-tindakan yang dikriminalisasi dalam suatu konvensi internasional sebagaimana juga yang terdapat dalam UNCAC memiliki karakteristik tersendiri. Pertama, perumusan tindakan yang dikriminalisasikan saling tumpang tindih antara satu dengan yang lain. Kedua, sebagai konsekuensi dari yang pertama, unsurunsur tindakan yang dikriminalisasikan menjadi tidak jelas. Tegasnya, perumusan yang demikian tidak memenuhi syarat lex certa $^{17}$ sebagai hal yang prinsip dalam asas legalitas. Ketiga, perumusan tindakan-tindakan yang dikriminalisasikan tidak diikuti oleh suatu sangksi pidana yang tegas.

Bila dihubungkan dengan asas legalitas dalam hukum pidana internasional tidaklah dapat disamakan dengan ukuran berlakunya asas legalitas dalam hukum pidana nasional. Selain karena hukum pidana internasional tidak dikodifikasi sebagaimana hukum pidana nasional, hukum pidana internasional juga bersumber dari kebiasaan internasional sehingga sangat dimungkinkan berlakunya asas legalitas adalah berdasarkan hukum kebiasaan internasional. Padahal, dalam konteks hukum pidana nasional ukuran berlakunya asas legalitas antara lain adalah lex scripta dan lex certa atau berdasarkan hukum tertulis dan aturan yang jelas sehingga tidak dibenarkan berlakunya asas legalitas hanya berdasarkan hukum kebiasaan. Demikian pula dalam konteks hukum pidana nasional ketentuan pidana harus diinterpretasikan secara ketat sebagai pengejawantahan prinsip lex stricta.

Karakteristik perumusan yang demikian bukan tidak ada tujuannya. Hal ini dimaksudkan agar pelaku kejahatan internasional dapat dijerat dengan berbagai perumusan yang tumpang tindih. Artinya, jangan sampai pelaku kejahatan internasional lolos dari hukuman. Selain itu, tidak dicantumkan sanksi pidana yang tegas dalam tindakan-tindakan yang 
dikriminalisasikan bertujuan memberi diskresi yang luas kepada hakim untuk menjatuhkan pidana dengan tetap menjunjung tinggi prinsip-prinsip dalam due process of law. Karakteristik yang demikian dengan mengingat bahwa korupsi adalah kejahatan luar biasa atau extra ordinary crime.

Berdasrkan UNCAC, ada tiga kejahatan akan diulas lebih lanjut, masing-masing memperdagangkan pengaruh, memperkaya secara tidak sah dan korupsi di sector swasta. PERTAMA, 'Traiding in influence' yang dalam UNCAC tercantum dalam Pasal 18. Jika diterjemahkan secara leterlijk, maka bunyi Pasal 18 adalah sebagai berikut: Setiap Negara Pihak dapat mempertimbangkan untuk mengambil tindakantindakan legislatif dan lainnya yang dianggap perlu untuk menetapkan kejahatan pidana, apabila dilakukan dengan sengaja: (1) Janji, penawaran atau pemberian kepada pejabat publik atau orang lain siapa pun, secara langsung atau tidak langsung manfaat yang tidak semestinya agar pejabat publik atau orang tersebut menyalahgunakan pengaruhnya yang nyata atau yang dianggap ada dengan maksud memperoleh dari otoritas administrasi atau publik dari Negara Pihak suatu manfaat yang tidak semestinya untuk kepentingan penghasut yang sebenarnya dari tindakan tersebut atau untuk orang lain siapa pun; (2) Permintaan atau penerimaan oleh pejabat publik atau orang lain siapa pun, secara langsung atau tidak langsung, manfaat yang tidak semestinya untuk dirinya atau untuk orang lain agar pejabat publik atau orang tersebut menyalahgunakan pengaruhnya yang nyata atau yang dianggap ada dengan maksud memperoleh dari otoritas administrasi atau publik dari Negara Pihak, suatu manfaat yang tidak semestinya.

Berdasarkan Pasal 18 a dan Pasal 18 b UNCAC yang telah dikutip di atas, adapun analisis terhadap kedua pasal tersebut ialah sebagai berikut : Pertama, adanya kata-kata '... dapat mempertimbangakan ....." menunjukan bahwa tindakan yang dikriminalisasikan sebagai 'traiding in influence' bersifat non madatotry offences. Artinya, tidak ada kesepakatan diantara state party untuk mengkriminalisasi tindakan tersebut sebagai tindak pidana korupsi. Kedua, hakikat Pasal 18a dan Pasal 18b UNCAC mendefinisikan 'traiding in influence' menjadi dua bagian, yakni active traiding in influence sebagaimana terdapat dalam Pasal 18a dan pasive traiding in influence sebagaimana yang terdapat dalam Pasal 18 b. Active traiding in influence berarti memberikan tawaran untuk memperdagangkan pengaruh, sedangkan passive traiding in influence berarti menerima tawaran memperdagangkan pengaruh.

Ketiga, bentuk kesalahan dalam pasal tersebut adalah kesengajaan yang berarti menghendaki adanya pengetahuan dan kehendak (weten en wilen) dari pelaku. Bahkan, kalau ditelaah lebih detil adanya kata-kata '... dengan maksud...' dalam pasal tersebut telah membatasi corak kesengajaannya adalah kesengajaan sebagai maksud. Artinya, pelaku menghendaki perbuatan berserta akibatnya. Kesengajaan sebagai maksud atau opzet als oogmerk adalah kesengajaan untuk mencapai suatu tujuan. Artinya, antara motivasi seseorang melakukan perbuatan, tindakan dan akibatnya benar-benar terwujud. Motivasi seseorang sangat mempengaruhi perbuatannya (affectio tua nomen imponit operi tuo). Opzet als oogmerk adalah bentuk kesengajaan yang paling sederhana. Konsekuensi lebih lanjut, corak kesengajaan lainnya yaitu kesengajaan sebagai kepastian dan kesengajaan sebagai kemungkinan (dolus eventualis atau inkauf nehmen) tidak memenuhi bentuk kesalahan dalam trading in influence. Perumusan yang demikian telah mempersempit ruang gerak jaksa penuntut umum untuk hanya membuktikan corak kesengajaan sebagai maksud.

Keempat, bentuk kesengajaan dengan corak kesengajaan sebagai maksud pada dasarnya tidak mudah untuk dibuktikan. Akan tetapi kesulitan untuk membuktikan corak kesengajaan sebagai maksud tersebut, diimbangi dengan wujud penyalahgunaan pengaruh yang sangat mudah dibuktikan. Hal ini tersirat dalam kata-kata, '...yang nyata atau yang dianggap ada...' Artinya, untuk membuktikan adanya penyalahgunaan pengaruh, tidak mesti ada 
penyalahgunaan pengaruh secara nyata tetapi cukup berdasarkan suatu anggapan bahwa perbuatan tersebut adalah penyalahgunaan pengaruh.

Kelima, untuk membuktikan corak kesengajaan sebagai maksud seperti yang terdapat dalam rumusan pasal tersebut biasanya dengan menggunakan teori kesengajaan yang diobjektifkan sehingga orang tersebut dianggap memperdagangkan pengaruh. Kesengajaan yang diobjektifkan sebenarnya bukanlah jenis kesengajaan melainkan cara untuk memastikan adanya kesengajaan. Terkait kesalahan, kesengajaan dan kelapaan adalah hubungan antara sikap batin pelaku dengan perbuatan yang dilakukan. Dalam rangka untuk menentukan adanya kesengajaan bukanlah perbuatan yang mudah bagi hakim. Tidaklah dapat ditentukan secara pasti apakah seseorang melakukan perbuatan dengan sengaja ataukah tidak. Dalam hal demikian, ada - tidaknya kesengajaan harus disimpulkan dari perbuatan yang tampak.

Keenam, subjek hukum yang dapat dipidana atau adresat dari pasal tersebut tidak hanya pejabat publik tetapi juga setiap orang baik yang mempunyai hubungan dengan pejabat publik tersebut maupun tidak. Dapatlah dikatakan rumusan pasal tersebut ada perluasan pertanggungjawaban pidana terhadap pelaku yang memperdagangkan pengaruh. Tidak hanya seseorang yang memperdagangkan pengaruh terhadap pejabat publik tetapi juga perantara dalam perbuatan memperdagangkan pengaruh dapat dimintakan pertanggungjawaban pidana. Tegasnya, rumusan pasal tersebut mengandung teori penyertaan yang ekstensif.

Ketujuh, terkait dengan traiding in influence dalam hubungannya dengan teori penyertaan yang ekstensif, mengingatkan kita pada Putusan Mahkamah Agung Tanggal 23 Desember 1955, Nomor 1/1955/MA Pid. Penyertaan yang ekstensif memandang bahwa pelaku tidak hanyamereka yang melakukan perbuatan secara materiil dan mempunyai syarat persoonlijk sebagaimana dirumuskan dalam rumusan delik tetapi lebih dari itu bahwa diantara para pelaku peserta, tidak perlu harus mempunya sifat dan karakteristik yang sama seperti dituangkan dalam rumusan delik. Hal ini sesuai dengan sejarah pembentukan Wetboek van Strafrecht ${ }^{18}$.

Singkat cerita Putusan Mahkamah Agung Tanggal 23 Desember 1955, Nomor 1/1955/MA Pid : Menteri Kehakiman saat itu Djodi Gondokusumo memberikan izin tinggal kepada seorang warga negara Cina yang telah di - persona non grata. Permintaan izin tinggal tersebut diajukan oleh warga negara Cina melalui dua orang pembantu Djodi dalam satu partai politik saat itu yang kebetulan tinggal bersama-sama dengan Djodi. Izin tinggal tesebut kemudian diberikan oleh Djodi atas permintaan kedua orang pembantunya. Setelah mendapatkan izin tinggal tersebut, Warga Negara Cina yang telah di - persona non grata memberikan sejumlah uang kepada kedua pembantu Djodi.

Mahakamah Agung dalam forum prevelegiatum yang memeriksa Djodi Gondokusumo menjatuhkan pidana penjara selama 6 bulan karena dianggap menerima pengaruh dari kedua pembantunya untuk memberikan izin tinggal dan dianggap mengetahui penyuapan antara warga negara Cina tersebut dengan kedua pembantu Djodi, kendatipun Djodi tidak pernah menerima uang suap tersebut. Artinya, Mahakamah Agung menganut teori penyertaan ekstensif. Di sini, twee of meer verenigde personen (dua atau lebih orang bersekutu) tidak perlu mempunyai sifat dan karakter yang sama, demikian pula motivasi dan kehendak yang sama dalam mewujudkan suatu tindak pidana. KEDUA, Illicit Enrichment dalam Pasal 20 UNCAC yang secara tegas menyatakan, "Tunduk kepada konstitusinya dan prinsip-prinsip dasar dari system hukumnya, setiap negara peserta dapat mempertmbangkan untuk mengadopsi tindakan-tindakan legislatif dan tindakan-tindakan

18 W.P.J Pompe, 1959, Handboek Van Het Nederlandse Strafrecht, Vijfde Herziene Druk, N.V. Uitgevers - Maatschappij W.E.J.Tjeenk Willink, Zwolle., hlm. 224. 
lain yang mungkin diperlukan untuk menetapkan sebagai suatu tindak pidana, bila dilakukan dengan sengaja, memperkaya secara tidak sah yaitu suatu kenaikan yang berarti dari aset-aset seorang pejabat publik yang tidak dapat dijelaskan secara masuk akal berkaitan dengan pendapatannya yang sah".

Berdasarkan konstruksi pasal yang demikian, adapun unsur-unsur yang harus dibuktikan adalah 1) pejabat publik; 2) dengan sengaja; 3 ) memperkaya diri sendiri secara tidak sah. Selanjutnya dalam pasal a quo dijelaskan bahwa memperkaya secara tidak sah berarti tidak dapat menjelaskan secara masuk akal kenaikan aset-aset dari seorang pejabat publik berkaitan dengan pendapatannya yang sah. Perihal illicit enrichment tidak perlu dimasukkan berdasarkan argumentasi: Pertama, pasal ini tidak menganut prinsip lex certa dalam perumusan suatu ketentuan pidana karena tidak dijelaskan perbuatan yang tidak sah seperti apa. Kedua, formulasi aturan yang tidak jelas sangat berbahaya bagi penegakkan hukum karena dengan mudah mengkriminalisasi perbuatan secara sepihak. Ketiga, illicit inrichment pada hakikatnya mempunyai padanan dalam Pasal 2 dan Pasal 3 Undang-Undang Tipikor. Bahkan, Pasal 2 dan Pasal 3 yang masih eksis memuat unsur yang lebih jelas dan tegas. Keempat, illicit inrichment dalam UNCAC bersifat non mandatory offences. Artinya, bersifat fakultatif bagi negara peserta untuk tidak memasukkannya ke dalam hukum nasional. Kejahatan yang bersifat non mandatory pada hakikatnya menunjukan ketidaksepahaman negara-negara peserta konvensi dalam menyatakan perbuatan tersebut sebagai korupsi.

Ketiga, perihal Corruption in private sector yang terdapat dalam UNCAC terdiri dari Penyuapan di sektor swasta dan penggelapan kekayaan di sektor swasta. Ketentuan ini merupakan hal baru dalam pemberantasan korupsi. Kendatipun Corruption in private sector bersifat non mandatory offences, namun perlu dipertimbangkan untuk dikmasukan sebagai tindak pidana korupsi dengan argumnetasi sebagai berikut: Pertama, korupsi yang terjadi di Indonesia hampir selalu melibatkan pihak swasta. Kedua, salah satu latarbelakang internasionalisasi kejahatan korupsi adalah karena korupsi dianggap merusak pasar. Dalam hal ini adalah korupsi di sektor pengadaan barang dan jasa yang selalu melibatkan swasta. Ketiga, ketentuan pasal-pasal a quo dalam UNCAC adalah untuk melindungi sektor swasta dari tindakan-tindakan koruptif setiap orang yang bekerja di sektor swasta tersebut.

\section{Pengaruh Asas-Asas Hukum Pidana Internasional}

Secara garis besar asas-asas hukum pidana internasional ada yang bersumber dari hukum internasional dan ada yang bersumber dari hukum pidana. Asas hukum pidana internasional yang bersumber dari hukum internasional secara garis besar dibedakan ke dalam asas umum dan asas khusus. ${ }^{19}$ Asas hukum pidana internasional yang berasal dari hukum internasional dan umum sifatnya adalah pacta sunt servanda. Asas tersebut merupakan asas hukum yang paling tua dan paling utama yang mengandung arti bahwa perjanjian yang dibuat mengikat para pihak ibarat undang-undang. ${ }^{20}$

Asas hukum internasional umum lainnya yang juga merupakan asas hukum pidana internasional adalah asas itikat baik atau good faith (Inggris) atau goede trouw (Belanda). Asas tersebut merupakan salah satu prinsip yang fundamental dalam hukum internasional bahwa semua kewajiban yang diembani oleh hukum internasional harus dilakukan dengan sebaik-baiknya. Berikutnya adalah asas civitas maxsima sebagai asas hukum pidana internasional yang bersumber dari asas hukum internasional umum. Dalam beberapa literatur asas civitas maxima dikenal dengan istilah asas imperium romanum atau asas roman empire. Asas ini mengandung arti bahwa ada sistem hukum universal yang dianut oleh semua bangsa di dunia dan harus dihormati serta dilaksanakan. ${ }^{21}$ Bila dikaitkan dengan teori hubungan antara hukum

\footnotetext{
Romli Atmasasmita, 2003, Pengantar Hukum Pidana Internasional, Refika Aditama, Bandung, hlm. 14

Malcolm N. Shaw, Op.cit, hlm. 81.

M. Cherif Bassiouni, Op.cit., hlm. 31
} 
internasional dan hukum nasional, asas civitas maxima ini sejalan dengan teori monisme yang melihat hukum internasional dan hukum nasional sebagai satu kesatuan sistem dengan menempatkan hukum internasonal di atas hukum nasional.

Asas hukum pidana internasional yang sangat penting dalam hubungan kerjasama antar negara yang berasal dari asas hukum internasional umum adalah asas timbal balik. Asas ini juga dikenal dengan asas resiprokal. Pada dasarnya asas resiprokal ini mengandung makna bahwa jika suatu negara menginginkan suatu perlakuan yang baik dari negara lain, maka negara yang bersangkutan juga harus memberi perlakuan yang baik terhadap negara tersebut. Dalam pemberlakuan Asas ini, UNCAC memang menitikberatkan pada kerjasama internasional dan agar Negara pihak memiliki kerjasama internasional dalam memberantas korupsi. $^{22}$

Asas hukum pidana internasional yang bersumber dari asas hukum internasional yang khusus sifatnya, antara lain adalah asas aut dedere aut punere dan asas aut dedere aut judicare. Asas aut dedere aut punere diciptakan oleh Hugo de Groot yang berarti pelaku kejahatan internasional diadili menurut hukum tempat di mana ia melakukan kejahatan. Asas aut dedere aut judicare dikemukakan oleh Cherif Bassiouni yang berarti setiap negara berkewajiban menuntut dan mengadili pelaku kejahatan internasional serta berkewajiban melakukan kerjasama dengan negara lain dalam rangka menahan, menuntut dan mengadili pelaku kejahatan internasional. ${ }^{23}$

Asas hukum pidana internasional yang bersumber dari hukum pidana antara lain adalah asas legalitas, asas teritorial dan asas nebis in idem. Machteld Boot dengan mengutip pendapat Jescheck dan Weigend, asas leglitas dalam hukum pidana nasional memiliki empat syarat. Pertama, nullum crimen, noela poena sine lege praevia. Artinnya tidak ada perbuatan pidana, tidak ada pidana tanpa undang-undang sebelumnya. Kedua, nullum crimen, nulla peona sine lege scripta. Artinya, tidak ada perbuatan pidana, tidak ada pidana tanpa undangundang tertulis. Ketiga, nullum crimen, nulla poena sine lege certa. Artinya, tidak ada perbuatan pidana, tidak ada pidana tanpa aturan undang-undang yang jelas. Kempat, nullum crimen, noela poena sine lege stricta. Artinya, tidak ada perbuatan pidana, tidak ada pidana tanpa undang-undang yang ketat.

Masih menurut Boot, asas legalitas dalam konteks hukum pidana internasional harus diterapkan dengan standar yang berbeda dengan hukum pidana nasional yang berkaitan dengan tanggung jawab pidana individu terhadap kejahatankejahatan internasional. Boot menegaskan hukum pidana internasional tidak dikodifikasikan seperti halnya hukum pidana nasional tetapi juga bersumber dari hukum kebiasaan internasional. Oleh karena itu asas legalitas tidak mengikat seluruhnya dalam konteks kejahatan-kejahatan di bawah hukum internasional ${ }^{24}$. Demikian pula Steven R. Ratner dan Jason S. Abrams bahwa dalam konteks hukum pidana internasional, asas legalitas memiliki dimensi khusus. Tidak seperti hukum pidana nasional di sebagian besar negara, hukum pidana internasional tidak dikodifikasikan dalam kitab undang-undang. Akibatnya, kejahatan-kejatahan berdasarkan asas legalitas pada level internasional tidak hanya berlandaskan perjanjian internasional tetapi juga berdasarkan hukum kebiasaan internasional ${ }^{25}$.

Selanjutnya adalah asas teritorial yang menyatakan bahwa perundang-undangan hukum pidana suatu negara berlaku bagi semua orang yang melakukan perbuatan pidana di negara tersebut, baik oleh warga negaranya sendiri maupun warga

\footnotetext{
22 Ndifon Neji and Felix Nyong, "Rethinking Civil Society Participation in the Implementation of the UN Convention Against Corruption in Nigeria", Journal of Economics and Sustainable Development, Vol.9, No.16, 2018.

24 Machteld Boot, 2001, Nullum Crimen Sine Lege and the Subject Matter Jurisdiction of the International Criminal Court: Genocide, Crimes Against Humanity, War Crimes, Intersentia Antwerpen - Oxford - New York, hlm. 19.

25 Steven R. Ratner dan Jason S. Abrams, 2001, Accountability for Human Rights Atrocities in International Law: Beyond the Nurember Legacy, Second Edition, Oxford University Press, hlm. 21.
} 
negara asing $^{26}$. Dalam rangka mengantisipasi berbagai kejahatan yang dilakukan di luar wilayah suatu negara, hukum pidana mengenal perluasan asas teritorial. Pertama, perluasan teknis yang dibagi menjadi perluasan teknis subjektif dan perluasan teknis objektif. Perluasan teknis subjektif membenarkan negara mempunyai kompetensi mengadili atas perbuatan yang mulai dilakukan di wilayahnya tetapi berakhir atau menimbulkan akibat di wilayah negara lain. Sedangkan perluasan teknis objektif membenarkan negara mempunyai kompetensi mengadili atas perbuatan yang mulai dilakukan di negara lain tetapi menimbulkan akibat di wilayahnya. ${ }^{27}$ Kedua, Perluasan berdasarkan kewarganegaraan yakni asas nasional aktif disebut juga asas personalitas yang berarti perundangundangan hukum pidana berlaku bagi semua perbuatan pidana yang dilakukan oleh warga negara di mana saja ia berada termasuk di luar wilayah negaranya dan asas nasional pasif pada hakekatnya adalah asas untuk melindungi kepentingan nasional sehingga aturan-aturan pidana suatu negara dapat diterapkan terhadap warga negara asing yang melakukan kejahatan di luar wilayah negara tersebut tetapi korban perbuatan pidana adalah warga negara tersebut. ${ }^{28}$

Ketiga, perluasan berdasarkan prinsip proteksi yakni perlindungan terhadap kepentingan nasional. Artinya, perundang-undangan hukum pidana suatu negara berlaku bagi semua orang di luar wilayah negaranya bila melakukan kejahatan yang bertalian dengan keamanan dan integritas atau kepentingan ekonomi negaranya ${ }^{29}$. Keempat, perluasan berdasarkan prinsip universal terkait dengan delicta jure gentium atau kejahatan terhadap masyarakat internasional. Artinya, perundangundangan hukum pidana suatu negara berlaku bagi semua orang yang melakukan pelanggaran terhadap hukum pidana internasional. Semua negara berhak untuk menangkap, mengadili dan menghukum pelaku kejahatan tersebut dengan tujuan agar kejahatan itu tidak lepas dari hukuman. ${ }^{30}$

Berikutnya adalah asas ne bis in idem atau principle of double jeopardy. Asas ini berarti seseorang tidak dapat dituntut lebih dari satu kali di depan pengadilan dengan perkara yang sama. Asas ini bertujuan untuk menjamin kepastian hukum dan melindungi hak asasi manusia.

\section{Raison D'Etre Implementasi UNCAC Di Indonesia}

Sebagaimana yang telah diuraikan di atas pada awal tulisan ini, diskursus terkait implementasi UNCAC, apakah UNCAC yang telah diratifikasi dengan Undang-Undang Nomor 7 Tahun 2006 dapat serta merta berlaku di Indonesia sebagai instrumen pemberantasan korupsi ataukah UNCAC yang telah diratifikasi harus disesuaikan dengan undang-undang nasional baru kemudian dapat diberlakukan ? Berdasarkan berbagai uraian di atas, Penulis berpendapat bahwa UNCAC dapat serta merta diimplementasikan sebagai instrumen pemberantasan korupsi. Paling tidak ada tujuh argumentasi sebagai analisis teoretis untuk memperkuat pendapat tersebut.

Pertama, berdasarkan UNCAC, korupsi adalah kejahatan internasional. Artinya, berlaku asas universal dalam hukum pidana bahwa setiap negara wajib melakukan penuntutan dan penghukuman terhadap pelaku kejahatan internasional. Kedua, ratifikasi UNCAC oleh Pemerintah Indonesia tentunya sudah didasarkan pada pertimbangan yang matang bahwa isi konvensi tersebut sesuai dengan situasi dan kondisi negara yang sedang giatgiatnya melakukan pemberantasan korupsi. Ketiga, ratifikasi yang dilakukan terhadap UNCAC berlaku sebagai self executing treaty. Artinya, dapat serta merta diberlakukan sebagai hukum positif.

Keempat, ratifikasi suatu konvensi

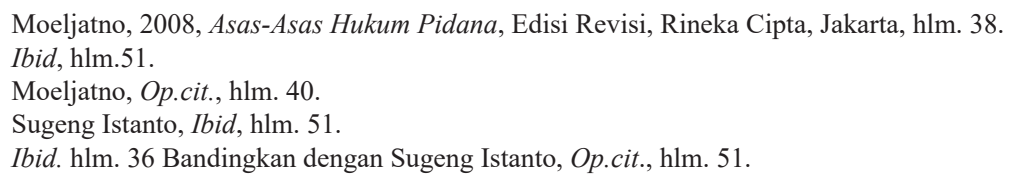


internasional tunduk pada prinsip umum hukum internasional yakni pacta sunt servanda yang berarti perjanjian yang dibuat oleh para pihak mengikat ibarat undang-undang. Menurut Oppenheim, sebagaiman yang dikutip oleh Anthony Aust, di dalam asas pacta sunt servanda tercakup asas keadilan dan itikat baik untuk melaksanakan isi suatu perjanjian atau konvensi yang telah dirativikasi. ${ }^{31}$ Kelima, dalam konteks hubungan antara hukum pindana internasional dengan hukum pidana nasional, hukum pidana internasional berfungsi sebagai pelengkap terhadap hukum pidana nasional, bilamana aturan-aturan yang berada dalam konvensi internasional yang telah diratifikasi belum diatur dalam undang-undang nasional. Sebagai tambahan pada argumentasi ini, bahkan ditegaskan dengan mengikuti UNCAC maka Indonesia akan memiliki kerjasama internasional yang lebih baik dengan Negara lain dalam pemberantasan tindak pidana korupsi. ${ }^{32}$

Keenam, berdasarkan asas hukum pidana internasional yakni asas civitas maxima secara tegas menyatakan bahwa hanya ada satu sistem hukum universal yang dianut oleh semua bangsa di dunia dan harus dihormati serta dilaksanakan. Ketujuh, korupsi sebagai kejahatan internasional yang merupakan substansi dari hukum pidana internasional dalam hubungan dengan paham monisme dan paham dualisme, hukum pidana internasional lebih menitikberatkan pada paham monisme bahwa hukum internasional dan hukum nasional merupakan satu kesatuan sistem hukum berupa kaidah-kaidah yang mengikat individu, negara maupun kesatuan lainnya yang bukan negara.

\section{Kesimpulan}

Berdasarkan penjabaran hal di atas dapat dinyatakan kesimpulan bahwa pada dasarnya Hukum Indonesia, terutama pada Undang-Undang Nomor 31 Tahun 1999 jo. Undang-Undang Nomo 20 Tahun 2001 tentang Pemberantasan Tindak Pidana Korupsi telah tertinggal dan tidak sesuai dengan United Nations Convention Against Corruption. Ketidak sesuaian tersebut, tentu berakibat pada lemahnya penegakkan hukum terhadap tindak pidana korupsi di Indonesia. Oleh karena itu, hukum pidana Indonesia menjadi penting untuk menyesuaikan dengan UNCAC yang telah Indonesia ratifikasi. Penyesuaian tersebut tidak hanya pada ranah hukum materiil, namun melingkupi perbaikan formil sehingga menciptakan perbaikan pada sistem peradilan pidana.

\section{DAFTAR PUSTAKA}

\section{A. Buku}

Andi Hamzah, 1984, Korupsi di Indonesia Masalah dan Pemecahannya, Gramedia Pustaka Utama.

Aust Anthony, 2005, Handbook of International Law, Cambridge University Press.

Bantekas Illias and Nash Susan, 2007, International Criminal Law, Third edition, Routledge Cavendish, London And New York.

Bassiouni M. Cherif, 2003, Introduction to
International Criminal Law, Transnational Publisher, Inc. Ardsley, New York.

Beirne Piers and Messerschmidt James, 1995, Criminology, second edition, Harcourt Brage College Publishers.

Boot Machteld, 2001, Nullum Crimen Sine Lege and the Subject Matter Jurisdiction of the International Criminal Court: Genocide, Crimes Against Humanity, War Crimes, Intersentia, Antwerpen - Oxford - New York.

Eddy O.S Hiariej, 2009, Pengantar Hukum Pidana Internasional, Erlangga, Jakarta.

Yenti Ganarsih, "Paradigma Baru dalam Pengaturan Anti Korupsi di Indonesia dikaitkan dengan UNCAC 2003", Jurnal Hukum Prioris, Volume 2, Nomor 3, September 2009, hlm. 163. 
Harris D.J., 1998, Cases and Materiils On International Law, Sweet \& Maxwell, London.

Hiariej Eddy O.S, 2009, Pengantar Hukum Pidana Internasional, Penerbit Erlangga.

Hiariej Eddy O.S, 2012, Pembuktian Terbalik Dalam Pengembalian Aset Kejahatan Korupsi, Pidato Pengukuhan Jabatan Guru Besar Pada Fakultas Hukum Universitas Gadjah Mada, Senin 30 Januari 2012.

Moeljatno, 2008, Asas-Asas Hukum Pidana, Edisi Revisi, Rineka Cipta, Jakarta

Ratner Steven R and Abrams Jason S, 2001, Accountability for Human Rights Atrocities in International Law: Beyond the Nurember Legacy, Second Edition, Oxford University Press.

Romli Atmasasmita, 2003, Pengantar Hukum Pidana Internasional, Refika Aditama.

Sahetapy J.E., 1997, Kejahatan Gotong Royong, Makalah Diskusi Panel Fakultas Hukum, 22 November 1997.

Saldi Isra dan Eddy O.S Hiariej, 2009, Perspektif Hukum Pemberantasan Korupsi di Indonesia, dalam Wijayanto dan Ridwan Zachrie (Editor), Korupsi Mengorupsi Indonesia : Sebab, Akibat dan Prospek Pemberantasan, Penerbit PT Gramedia Pustaka Umum Jakarta.

Shaw Malcolm N., 2004, International Law, $5^{\text {th }}$ Edition, Cambridge University Press.
Sudikno Mertokusumo, 2003, Mengenal Hukum: Suatu Pengantar, Liberty, Yogyakarta.

Starke J.G., 2001, Pengantar Hukum Internasional, 1, Edisi Kesepuluh, Sinar Grafika, Jakarta.

Sugeng Istanto, 1998, Hukum Internasional, Penerbitan Universitas Atma Jaya Yogyakarta.

\section{B. Jurnal}

Ganarsih, Yenti, "Paradigma Baru dalam Pengaturan Anti Korupsi di Indonesia dikaitkan dengan UNCAC 2003", Jurnal Hukum Prioris, Vol. 2, No. 3, September 2009.

Ginting, Jamin, "Perjanjian Internasional Dalam Pengembalian Aset Hasil korupsi di Indonesia”, Jurnal Dinamika Hukum, Vol. 11, No. 3, September 2011.

Neji, Ndifon and Felix Nyong, "Rethinking Civil Society Participation in the Implementation of the UN Convention Against Corruption in Nigeria", journal of economics and sustainable development, Vol.9, No.16, 2018.

Peters, Anne, "Corruption as a Violation of International Human Rights", The European Journal of International Law, Vol. 29, No. 4, 2018.

Sanyal, Rajib, "Determinants of Bribery in International Business: The Cultural and Economic Factors", Journal of Business ethics, Vol 59, 2005. 